\title{
Effects of ground cover from branches of arboreal species on weed growth and maize yield ${ }^{1}$
}

\author{
Efeitos da cobertura do solo com ramos de espécies arbóreas no crescimento das \\ plantas daninhas e rendimento do milho
}

\author{
Paulo Sérgio Lima e Silva ${ }^{2 *}$, Vianney Reinaldo de Oliveira ${ }^{3}$, Paulo Igor Barbosa e Silva ${ }^{4}$, Larissa da Silva Chicas ${ }^{5}$ \\ e Francisco Linco de Souza Tomaz
}

\begin{abstract}
Cultivating maize under systems of alley cropping results in improvements to the soil, a reduction in weeds and an increase in yield. Studies using ground cover from tree shoots produce similar results. The aim of this study was to evaluate the effects on weed growth and maize yield of ground cover made up of 30 tha-1 (fresh matter) of branches from the tree species: neem (Azadirachta indica A. Juss), gliricidia [Gliricidia sepium (Jacq.) Kunth ex Walp.], leucaena [Leucaena leucocephala (Lam.) de Wit.] and sabiá (Mimosa caesalpiniifolia Benth.). Two treatment groups (cultivars and weed control) were evaluated. The cultivars AG 1041 and AL Bandeirantes were subjected to the following treatments: no hoeing, double hoeing, and ground a cover of branches of the above species when sowing the maize. A randomised block design was used with split lots (cultivars in the lots) and ten replications. The cultivars did not differ for green ear or grain yield. Double hoeing was more effective than ground cover at reducing the growth of weeds. However, both weeding and ground cover resulted in similar yields for green ears and grain, which were greater than those obtained with the unweeded maize.
\end{abstract}

Key words: Zea mays. Azadirachta indica. Gliricidia sepium. Leucaena leucocephala. Mimosa caesalpiniifolia. Hoeing. Green corn.

RESUMO - O cultivo do milho em sistema de aléias resulta em melhoria do solo, redução das plantas daninhas e aumento do rendimento. Os trabalhos com a cobertura do solo com a parte aérea de árvores produz resultados semelhantes. $\mathrm{O}$ objetivo deste trabalho foi avaliar os efeitos da cobertura do solo com $30 \mathrm{t} \mathrm{ha}^{-1}$ (matéria fresca) de ramos das espécies arbóreas nim (Azadirachta indica A. Juss), gliricídia [Gliricidia sepium (Jacq.) Kunth ex Walp.], leucena [Leucaena leucocephala (Lam.) de Wit.] e sabiá (Mimosa caesalpiniifolia Benth.) sobre o crescimento das plantas daninhas e sobre o rendimento do milho. Dois grupos de tratamentos (cultivares e controle de plantas daninhas) foram avaliados. As cultivares AG 1041 e AL Bandeirantes foram submetidas aos seguintes tratamentos: sem capinas, duas capinas e cobertura do solo, por ocasião da semeadura do milho, com ramos das espécies referidas. Utilizou-se o delineamento de blocos casualizados com parcelas subdivididas (cultivares nas parcelas) e dez repetições. As cultivares não diferiram quantos aos rendimentos de espigas verdes e de grãos. A realização de duas capinas foi mais eficiente na redução do crescimento das plantas daninhas do que a cobertura do solo. Entretanto, as capinas e a cobertura do solo propiciaram rendimentos semelhantes de espigas verdes e de grãos, que foram superiores aos obtidos no milho não capinado.

Palavras-chave: Zea mays. Azadirachta indica. Gliricidia sepium. Leucaena leucocephala. Mimosa caesalpiniifolia. Capina. Milho verde.

\footnotetext{
DOI: $10.5935 / 1806-6690.20150069$

* Autor para correspondência

${ }^{1}$ Recebido para publicação em 07/08/2014; aprovado em 29/07/2015

Trabalho realizado com o apoio do $\mathrm{CNPq}$

${ }^{2}$ Departamento de Ciências Vegetais/Melhoramento Vegetal, Universidade Federal Rural do Semi-Árido/UFERSA, Brasil, paulosergio@ufersa.edu.br ${ }_{3}^{3}$ Departamento de Ciências Vegetais/Fitotecnia, Universidade Federal Rural do Semi-Árido/UFERSA, Brasil, vianney.reinaldo@ gmail.com ${ }^{4}$ Estudante, Departamento de Ciências Vegetais/Fitotecnia, Universidade Federal Rural do Semi-Árido/UFERSA, Brasil, pauloigorbs@gmail.com, chicolinco@hotmail.com

55Departamento de Biologia/Biotecnologia, Universidade Federal do Ceará/UFC, Fortaleza-CE, Brasil, larissa_chicas@hotmail.com
} 


\section{INTRODUCTION}

The soils of the Brazilian semi-arid region are generally not very fertile. In this region, as in other regions of Brazil and the world, so-called itinerant farming is common (LOJKA et al., 2011; MAMEDE; ARAÚJO, 2008). This type of farming involves cutting and burning the Caatinga vegetation with crop cycles of from three to five years. Little fertilizer is used because limited resources and low rainfall restrict any potential return on investment in fertilizer (TIESSEN; SALCEDO; SAMPAIO, 1992). Crop yield decreases after the first year under cultivation when the fertilizing effect from the ashes and from the decomposition of organic material decreases. Crop cycles are followed by a cycle of ten years or more of lying fallow, during which fertility is restored and the native vegetation is partially re-established (TIESSEN; SALCEDO; SAMPAIO, 1992). Because of these and other problems with conventional agriculture (monocrops, for example), some researchers have recommended sustainable farming practices (SCHROTH; RUF, 2014).

Sustainable farming aims to maintain crop yields, reduce production costs and preserve the environment (CARVALHO, 2006). Among suggested sustainable farming practices, agroforestry systems have received great attention, including in the northeast of Brazil (DRUMOND; MORGADO, 2004). Agroforestry consists of systems and technologies in which perennial plant species are used in the same area with agricultural crops and/or animals in some form of spatial arrangement or temporal sequence. Agroforestry systems provide greater sustainability and have more economic advantages than itinerant agriculture (RAHMAN et al., 2007). There are several types of agroforestry systems in the world, but one of the most common is alley cropping.

In alley cropping, trees or shrubs, usually leguminous, are grown in rows interspersed with rows of agricultural crops (BERTALOT et al., 2010). Such systems are managed by pruning the shoots of the trees at the start of the growing season of the main crop, with the product of this pruning then being applied to the soil where it decomposes and provides nutrients to the plants (PEREZMARIN; MENEZES; SALCEDO, 2007). Studies of alley cropping with maize have shown that improvements to the soil, a reduction in weeds and an increase in yield take place (BERTALOT et al., 2010; QUEIROZ et al., 2007). Based on these results, several studies have been conducted using the shoots of arboreal species as ground cover in a type of simulation of alley cropping. Some of these studies have demonstrated, similarly to the alley cropping studies, that ground cover using tree shoots improves the properties of the soil, controls weeds and increases maize and other crops yield (MASHINGAIDZE et al., 2012; MULVANEY; OMOVBUDE; UDENSI, 2012; PRICE; WOOD, 2011; ; RAJASHEKARAPPA; BASAVARAJAPPA; PUTTAIAH, 2013).

Controlling weeds with ground cover may be of great interest to many regions of the world where weeds are controlled by hoeing. Hoeing is laborious, expensive and time-consuming and is therefore often not carried out in time before the weeds cause damage to the crop.

The aim of this study was to evaluate the effects of soil cover using branches of the tree species (Azadirachta indica, Gliricidia sepium, Leucaena leucocephala, Gliricidia sepium and Mimosa caesalpiniifolia) on weed growth and maize yield. All these species are well adapted to the Brazilian semi arid region.

\section{MATERIAL AND METHODS}

The study was carried out on the Rafael Fernandes Experimental Farm of the Federal Rural University of the Semi-Arid (UFERSA) from August to September 2009. This farm is located in the district of Alagoinha, $20 \mathrm{~km}$ from the town of Mossoró ( $5^{\circ} 11^{\prime} \mathrm{S}, 37^{\circ} 20^{\prime} \mathrm{W}$, at an elevation of $18 \mathrm{~m}$ ) in the state of Rio Grande do Norte, Brazil. Under the Gaussen bioclimatic system, the climate in the region of Mossoró is classified as type 4ath, distinctly xerothermic (i.e., tropical hot), with a pronounced dry season lasting from seven to eight months, and a xerothermic index of between 150 and 200. The region has a maximum average air temperature of between 32.1 and $34.5^{\circ} \mathrm{C}$ and an average minimum of between 21.3 and $23.7^{\circ} \mathrm{C}$, with June and July being the coldest months. The average annual rainfall is approximately $825 \mathrm{~mm}$. Sunlight increases from March to October, with an average of $241.7 \mathrm{~h}$; the maximum relative humidity reaches $78 \%$ in April with a minimum of $60 \%$ in September (CARMO FILHO; OLIVEIRA, 1989).

Under the Brazilian System of Soil Classification (Embrapa, 2006), the soil in the experimental area is classified as a Red-Yellow Argisol. Analysis of a soil sample collected at a depth of 0-20 cm gave the following result: $\mathrm{pH}\left(\mathrm{H}_{2} \mathrm{O}\right)=6.1$, organic matter $=21 \mathrm{~g} \mathrm{dm}^{-3}, \mathrm{P}$ $($ Mehlic-1 $)=15 \mathrm{mg} \mathrm{dm}^{-3}, \mathrm{~K}^{+}=2.7 \mathrm{mmol}_{\mathrm{c}} \mathrm{dm}^{-3}, \mathrm{Ca}^{2+}=$ $20 \mathrm{mmol}_{\mathrm{c}} \mathrm{dm}^{-3}, \mathrm{Mg}^{2+}=7 \mathrm{mmol}_{\mathrm{c}} \mathrm{dm}^{-3}$ and $\mathrm{H}^{+}+\mathrm{Al}^{3}+=$ $12 \mathrm{mmol}_{\mathrm{c}} \mathrm{dm}^{-3}$.

The soil was prepared by tractor, harrowed twice, and received as sowing fertilizer $1 / 3$ of the total $\mathrm{N}$ applied $\left(120 \mathrm{~kg} \mathrm{ha}^{-1}\right), 60 \mathrm{~kg} \mathrm{P}_{2} \mathrm{O}_{5}$ and $40 \mathrm{~kg} \mathrm{~K}_{2} \mathrm{O}$ per ha. The remaining $\mathrm{N}$ was applied in equal parts after each hoeing. Ammonium sulfate, single superphosphate and potassium chloride were used as sources of $\mathrm{N}, \mathrm{P}_{2} \mathrm{O}_{5}$ and $\mathrm{K}_{2} \mathrm{O}$, respectively. The spacing between rows was $1.0 \mathrm{~m}$, with the holes in any one row spaced $0.40 \mathrm{~m}$ apart. Sowing 
was performed manually with four seeds per hole. At 20 days after sowing, the plants were thinned, leaving the two largest plants in each hole and giving the experiment a planned seeding density of 50 thousand plants ha- $\mathrm{h}^{-1}$.

Control of the fall armyworm (Spodoptera frugiperda Smith), the main pest affecting the crop in this region, was carried out by spraying with 0.0 diethyl 0-(3,5,6-trichloro-2-pyridyl) thiophosphate $\left(0.4 \mathrm{~L} \mathrm{ha}^{-1}\right)$ using a backpack sprayer.

The experiment was conducted under sprinkler irrigation. The depth of water needed by the maize (5.3 $\mathrm{mm}$ ) was calculated taking the effective depth of the root system to be $0.40 \mathrm{~m}$. When to irrigate was based on the water retained in the soil at a pressure of 0.40 $\mathrm{MPa}$. Irrigation began after sowing was carried out three times a week and was suspended five days before the mature ears were harvested.

A randomized complete-block experimental design was used with ten replications and split plots. Each lot consisted of four rows $6.0 \mathrm{~m}$ in length. The useful area was considered as being the area occupied by the two central rows, with the plants from one hole at each end being disregarded. The cultivars AG 1041 and AL Bandeirantes (plots) were subjected to the following treatments (subplots): no hoeing, two hoeings (at 20 and 40 days after sowing the maize), and ground cover of 30 $\mathrm{t} \mathrm{ha}^{-1}$ (fresh weight) of the shoots (leaves and branches having a diameter of approximately $1.0 \mathrm{~cm}$ ) of neem, gliricidia, leucaena and sabiá). The proportion of dry matter (as a percentage) from the branches of each of these species, based on the average of three samples and determined at the time the treatment was applied, was 33.1, 27.8, 32.3 and 44.5, respectively. The first three species are exotic but well-adapted to the Brazilian semiarid region (KIILL; MENEZES, 2005), whereas sabiá is native to the semi-arid region (MAIA, 2004). Weeding was carried out with a hoe, always assigning the same employee to do the work in each block.

One of the two rows from the useful area of each lot was used randomly to evaluate the yield of green corn and the other to assess the yield of mature corn (dry). Green corn yield was assessed from the total number and weight of the ears and from the number and weight of marketable, unhusked and husked ears. The green ears were harvested when the grains exhibited a water content of between $70 \%$ and $80 \%$, at 70-75 days after sowing. Marketable unhusked ears were considered to be those having a suitable appearance for marketing and a length of not less than $22 \mathrm{~cm}$. Marketable husked ears were considered to be those with health and gradation suitable for marketing and a length of not less than $17 \mathrm{~cm}$. These criteria were adopted based on the ears that are marketed in the region where the study was carried out. The mature ears, harvested when the grains had a water content of approximately $20 \%$, were left to dry and then threshed by hand.

After harvesting the ripe corn at 100 days after sowing, plant height and ear insertion in the maize were evaluated, as were the characteristics of the weeds. Plant height and ear insertion were measured in all of the plants from the same row used to evaluate grain yield. The height of the maize plants was considered to be the distance from ground level to insertion of the highest leaf blade; the height of ear insertion was measured from ground level to the base of the highest ear (first ear in the case of prolific plants). An area of $1.0 \mathrm{~m}$ x $1.0 \mathrm{~m}$ was set out in the center of the space between the two central rows of the lot. Weeds present in each of these areas were cut close to the ground, weighed and identified. A $200 \mathrm{~g}$ sample of these plants was placed into a forced air circulation oven set to a controlled temperature of $70{ }^{\circ} \mathrm{C}$ until reaching constant weight to assess weed growth.

Data from the maize and weeds were submitted to a test for homogeneity of variance prior to variance analysis. The means were compared at $5 \%$ probability by Tukey test.

\section{RESULTS AND DISCUSSION}

The species of weeds that occurred most frequently in the experiment (in percentages of the total number of experimental units) were: Alternanthera tenella Colla (70), Cucumis anguria L. (63), Commelina benghalensis L. (58), Blainvillea acmella (L.) Philipson (27), Digitaria sanguinalis Scop. (15), Cenchrus equinatus L. (13) and Phyllanthus amarus Schumach. \& Thonn. (12). Other species occurred at frequencies of less than $8 \%$.

There was an effect from cultivar (C) on the fresh and dry weed matter, but not from the method of weed control (M) or the interaction of $\mathrm{C} \times \mathrm{M}$ (Table 1). The effects from the method of weed control were different for the fresh and dry weed matter (Table 2). This may happen because the distribution of weeds in fields is not uniform (CARDINA; JOHNSON; SPARROW, 1997), with weed samples collected from different lots consequently differing in water content. For both characteristics, either hoeing or ground cover resulted in lower averages than in the unweeded maize, except for the leucaena branch treatment in the case of fresh biomass. Hoeing twice was more efficient than ground cover at reducing weed growth, almost certainly due to this method, which eliminated a greater proportion of weeds than the ground cover. There were differences among the ground covers in their effect 
Table 1 - Summary of the variance analysis for weed biomass and maize cultivar characteristics in response to the methods of weed control (MWC)

\begin{tabular}{|c|c|c|c|c|c|}
\hline \multirow{3}{*}{ Source of variation } & \multirow{3}{*}{ Degrees of freedom } & \multicolumn{2}{|c|}{ Weed biomass $\left(\mathrm{g} \mathrm{m}^{-2}\right)$} & \multicolumn{2}{|c|}{ Corn height $(\mathrm{cm})$} \\
\hline & & Fresh & Dry & Plant & Ear \\
\hline & & \multicolumn{4}{|c|}{ 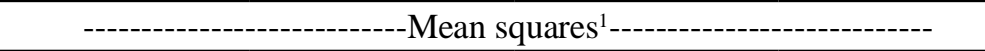 } \\
\hline Blocks & 9 & $1,485,606.1$ & $26,834.0$ & 225.3 & 150.2 \\
\hline Cultivars & 1 & $366,528.5^{\text {ns }}$ & $76.8^{\text {ns }}$ & $3,774.4^{*}$ & $5.6^{\mathrm{ns}}$ \\
\hline Error 1 & 9 & $104,760.0$ & $9,554.0$ & 141.4 & 100.8 \\
\hline MWC & 5 & $13,280,354.2 * *$ & $473,015.9 * *$ & $4,274.4 * *$ & $2,651.1 * *$ \\
\hline $\mathrm{C} \times \mathrm{MWC}$ & 5 & $415,466.4^{\mathrm{ns}}$ & $11,621.3^{\mathrm{ns}}$ & $100.9^{\mathrm{ns}}$ & $77.8^{\mathrm{ns}}$ \\
\hline Error 2 & 90 & $331,659.5$ & $150,36.8$ & 242.8 & 158.1 \\
\hline
\end{tabular}

${ }^{1} \mathrm{~ns}, *, * *$ Corresponding to a non-significant or significant effect at $5 \%$ or at $1 \%$ probability, respectively, by F-test

Table 2 - Mean fresh and dry mass of weed shoots in a maize crop and plant height and ear height in maize cultivars as a response to methods of weed control ${ }^{1}$

\begin{tabular}{lcccc}
\hline \multirow{2}{*}{ Method of weed control ${ }^{2}$} & \multicolumn{2}{c}{ Mass of weed shoots $\left(\mathrm{g} \mathrm{m}^{-2}\right)$} & Corn height $(\mathrm{cm})$ \\
\cline { 2 - 5 } & Fresh & Dry & Plant & Ear \\
\hline No hoeing & $2,719 \mathrm{a}$ & $529 \mathrm{a}$ & $163 \mathrm{c}$ & $\mathrm{c}$ \\
Two hoeings & $432 \mathrm{c}$ & $73 \mathrm{~d}$ & $181 \mathrm{~b}$ & $113 \mathrm{a}$ \\
Ground cover of gliricidia branches & $1,333 \mathrm{~b}$ & $220 \mathrm{~b}$ & $203 \mathrm{a}$ & $108 \mathrm{a}$ \\
Ground cover of leucaena branches & $2,324 \mathrm{a}$ & $338 \mathrm{c}$ & $197 \mathrm{a}$ & $102 \mathrm{ab}$ \\
Ground cover of Neem branches & $1,310 \mathrm{~b}$ & $210 \mathrm{~b}$ & $193 \mathrm{ab}$ & $107 \mathrm{a}$ \\
Ground cover of sabiá branches & $1,443 \mathrm{~b}$ & $231 \mathrm{bc}$ & $195 \mathrm{ab}$ & $101 \mathrm{~A}$ \\
\hline Cultivar & & & $183 \mathrm{~B}$ & $101 \mathrm{~A}$ \\
\hline AG 1051 & $1,538 \mathrm{~A}$ & $268 \mathrm{~A}$ & $194 \mathrm{~A}$ & 10.0 \\
$\mathrm{AL}$ Bandeirantes & $1,649 \mathrm{~A}$ & $266 \mathrm{~A}$ & 6.3 & 8.3 \\
\hline $\mathrm{CV}_{\text {plots }}(\%)$ & 20.3 & 36.6 & 46.0 & 12.5 \\
\hline $\mathrm{CV}_{\text {sublots }}(\%)$ & 36.1 & & & \\
\hline
\end{tabular}

${ }^{1}$ Means followed by the same letter do not differ significantly at $5 \%$ probability by Tukey's test; ${ }^{2}$ Ground cover consisted of $30 \mathrm{t} \mathrm{ha}{ }^{-1}$ (fresh weight) of Gliricidia sepium, Leucaena leucocephala, Azadirachta indica or Mimosa caesalpiniifolia

on weed growth, with leucaena being the least efficient. Of the four species studied, leucaena has the smallest leaflets, and this may be associated with its reduced efficiency as ground cover, both physically and due to decomposing more rapidly (PANDEY; SHARMA; BARGALI, 2006).

Ground cover can affect weed emergence through physical, biological and/or chemical processes, with possible interactions between them. Physical effects are important for photoblastic positive seeds and for those that need a great range in daily temperature variation to start the germination process (PITELLI; DURIGAN, 2001). Furthermore, ground cover reduces the chances of survival of seedlings with limited reserves in their seeds.
Some biological actions can benefit from the presence of ground cover, as this creates conditions for the installation of a dense and diverse micro-biocenosis. Microorganisms may cause deterioration and loss of viability in the various types of propagules and seedlings in the soil. Additionally, straw forms a shelter for animals that feed on seeds and weed shoots (PITELLI; DURIGAN, 2001). Chemical effects are related to allelopathic phenomena, changes in the carbon to nitrogen ratio $(\mathrm{C} / \mathrm{N})$, and the immobilization and recycling of nutrients (QUEIROZ et al., 2010). Allelopathic effects have been seen in the species studied in this work, i.e., in gliricidia (RAMAMOORTHY; PALIWAL, 1993), leucaena (CHOU; KUO, 1986), neem (SILVA et al., 2007) and sabiá (FERREIRA et al., 2010). 
There was an effect of the cultivar (C) and the method of weed control (M) on plant height, but not from the interaction of $\mathrm{C} \times \mathrm{M}$ (Table 1). The cultivar AL Bandeirantes exhibited taller plants than did the cultivar AG 1041 (Table 2). Height in the maize plant is considered the most predictive feature of suppressive ability and tolerance to weeds in maize, although other characteristics, such as foliage and the leaf angle are also relevant. (ZYSTRO; LEON; TRACY, 2012). The height of ear insertion was affected by the method of weed control (Table 1). Interestingly, maize from the lots with ground cover exhibited greater plant height and ear insertion than either the hoed or unweeded maize (Table 2). It is possible that in addition to weed control, soil cover improves the physical, chemical and biological properties of the soil, favoring greater maize growth in terms of plant height and ear insertion.

There was an effect from the method of weed control on total and marketable unhusked and husked green ears (Table 3). There was no difference between carrying out two hoeings and using ground cover from tree branches, these being superior to unweeded maize for these characteristics (Table 4).

There was also an effect from the method of weed control on the total weight and marketable weight of unhusked and husked green ears (Table 5). There was

Table 3 - Summary of the variance analysis for characteristics of maize cultivars as a response to the methods of weed control (MWC)

\begin{tabular}{|c|c|c|c|c|}
\hline \multirow{3}{*}{ Source of variation } & \multirow{3}{*}{ Degrees of freedom } & \multicolumn{3}{|c|}{ Number of ears per ha } \\
\hline & & Total & Marketable unhusked & Marketable husked \\
\hline & & \multicolumn{3}{|c|}{--on squares ${ }^{1}-{ }_{-}$} \\
\hline Blocks & 9 & $33,468,647.4$ & $72,784,700.8$ & $133,878,658.7$ \\
\hline Cultivars & 1 & $10,691,673 \cdot 0^{\mathrm{ns}}$ & $25,920,037.0^{\text {ns }}$ & $20,291,075.2^{\mathrm{ns}}$ \\
\hline Error 1 & 9 & $10,782,819.5$ & $57,793,432.8$ & $70,763,262.0$ \\
\hline MWC & 5 & $50,966,784.5^{*}$ & $1,083,260,530.0^{*}$ & $1,189,037,050.0^{*}$ \\
\hline C x MWC & 5 & $27,691,714.2^{\mathrm{ns}}$ & $71,315,896.1^{\mathrm{ns}}$ & $60,045,349.5^{\mathrm{ns}}$ \\
\hline Error 2 & 90 & $14,181,409.2$ & $48,431,881.7$ & $52,081,472.3$ \\
\hline
\end{tabular}

${ }^{1} \mathrm{~ns}$, *Corresponding to a non-significant or significant effect at $1 \%$ probability, respectively, by F-test

Table 4 - Mean values for green-ear yield in corn cultivars as a response to methods of weed control ${ }^{1}$

\begin{tabular}{lccc}
\hline \multirow{2}{*}{ Method of weed control ${ }^{2}$} & \multicolumn{3}{c}{ Number of ears per ha } \\
\cline { 2 - 4 } & Total & Marketable unhusked & Marketable husked \\
\hline No hoeings & $47,635 \mathrm{~b}$ & $25,915 \mathrm{~b}$ & $18,832 \mathrm{~b}$ \\
Two hoeings & $51,603 \mathrm{a}$ & $43,884 \mathrm{a}$ & $35,670 \mathrm{a}$ \\
Ground cover of gliricidia branches & $50,293 \mathrm{ab}$ & $43,662 \mathrm{a}$ & $38,956 \mathrm{a}$ \\
Ground cover of leucaena branches & $50,361 \mathrm{ab}$ & $43,846 \mathrm{a}$ & $38,411 \mathrm{a}$ \\
Ground cover of Neem branches & $52,256 \mathrm{a}$ & $45,000 \mathrm{a}$ & $37,978 \mathrm{a}$ \\
Ground cover of sabiá branches & $49,947 \mathrm{ab}$ & $42,956 \mathrm{a}$ & $36,307 \mathrm{a}$ \\
\hline Cultivar & & & $34,770 \mathrm{~A}$ \\
\hline AG 1051 & $50,648 \mathrm{~A}$ & $41,342 \mathrm{~A}$ & $33,948 \mathrm{~A}$ \\
Al Bandeirantes & $50,051 \mathrm{~A}$ & $40,412 \mathrm{~A}$ & 24.5 \\
\hline $\mathrm{CV}_{\text {plots }}(\%)$ & 6.5 & 18.6 & 21.0 \\
$\mathrm{CV}_{\text {sublots }}(\%)$ & 7.5 & 17.0 & \\
\hline
\end{tabular}

${ }^{1}$ Means followed by the same letter do not differ significantly at 5\% probability by Tukey's test; ${ }^{2}$ Ground cover consisted of $30 \mathrm{t}$ ha ${ }^{-1}$ (fresh weight) of Gliricidia sepium, Leucaena leucocephala, Azadirachta indica or Mimosa caesalpiniifolia 
Table 5 - Summary of the variance analysis for the characteristics of maize cultivars as a response to the methods of weed control (MWC)

\begin{tabular}{|c|c|c|c|c|}
\hline \multirow{3}{*}{ Source of variation } & \multirow{3}{*}{ Degrees of freedom } & \multicolumn{3}{|c|}{ Weight of ears $\left(\mathrm{kg} \mathrm{ha}^{-1}\right)$} \\
\hline & & Total & Marketable unhusked & Marketable husked \\
\hline & & \multicolumn{3}{|c|}{ 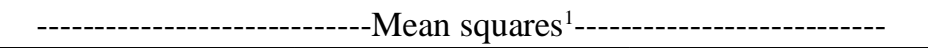 } \\
\hline Blocks & 9 & $9,553,079.2$ & $9,038,113.6$ & $4,193,623.5$ \\
\hline Cultivars & 1 & $1,894,550.7^{\mathrm{ns}}$ & $1,236,473.0^{\mathrm{ns}}$ & $3,579,380.2^{\mathrm{ns}}$ \\
\hline Error 1 & 9 & $6,714,083.1$ & $6,200,830.3$ & $4,365,788.5$ \\
\hline MWC & 5 & $168,877,916.8 *$ & $245,601,940.3 *$ & $99,542,828.5^{*}$ \\
\hline C x MWC & 5 & $5,563,690.9^{\text {ns }}$ & $7,720,803 \cdot 0^{\mathrm{ns}}$ & $4,301,614.4^{\mathrm{ns}}$ \\
\hline Error 2 & 90 & $5,410,565.9$ & $6,537,228.1$ & $2,970,437.8$ \\
\hline
\end{tabular}

${ }^{1} \mathrm{~ns}, *$ Corresponding to a non-significant or significant effect at $1 \%$ probability, respectively, by F-test

Table 6 - Mean values for green-ear yield in corn cultivars as a response to the methods of weed control ${ }^{1}$

\begin{tabular}{lccc}
\hline \multirow{2}{*}{ Method of weed control ${ }^{2}$} & \multicolumn{3}{c}{ Weight of ears $\left(\mathrm{kg} \mathrm{ha}^{-1}\right)$} \\
\cline { 2 - 4 } & \multicolumn{1}{c}{ Total } & Marketable unhusked & Marketable husked \\
\hline No hoeing & $7,205 \mathrm{~b}$ & $5,008 \mathrm{~b}$ & $2,288 \mathrm{~b}$ \\
Two hoeings & $13,343 \mathrm{a}$ & $12,774 \mathrm{a}$ & $6,810 \mathrm{a}$ \\
Ground cover of gliricidia branches & $14,697 \mathrm{a}$ & $14,096 \mathrm{a}$ & $8,169 \mathrm{a}$ \\
Ground cover of leucaena branches & $14,550 \mathrm{a}$ & $13,808 \mathrm{a}$ & $8,094 \mathrm{a}$ \\
Ground cover of neem branches & $14,488 \mathrm{a}$ & $13,656 \mathrm{a}$ & $7,496 \mathrm{a}$ \\
Ground cover of sabiá branches & $14,017 \mathrm{a}$ & $13,252 \mathrm{a}$ & $7,523 \mathrm{a}$ \\
\hline Cultivar & & & $6,903 \mathrm{~A}$ \\
\hline AG 1051 & $12,924 \mathrm{~A}$ & $11,997 \mathrm{~A}$ & $6,557 \mathrm{~A}$ \\
Al Bandeirantes & $13,175 \mathrm{~A}$ & $12,200 \mathrm{~A}$ & 31.0 \\
\hline CV & 19.9 & 20.6 & 25.6 \\
CV & 17.8 & 21.1 & \\
\hline
\end{tabular}

${ }^{1}$ Means followed by the same letter do not differ significantly at $5 \%$ probability by Tukey's test; ${ }^{2}$ Ground cover consisted of $30 \mathrm{t} \mathrm{ha}^{-1}$ (fresh weight) of Gliricidia sepium, Leucaena leucocephala, Azadirachta indica or Mimosa caesalpiniifolia

no difference between carrying out two hoeings and the use of ground cover from tree branches, these being superior to unweeded maize for these characteristics (Table 6).

Of the three components of grain yield, there was only a difference between cultivars for the number of grains per ear (Table 7), provided that the cultivars did not differ in the number of ears ha $^{-1}$ (estimated from the total number of green ears, shown in Table 2 ). There was also no difference between cultivars for grain yield (Table 7). There was no difference between carrying out two hoeings and using ground cover from tree branches, these being superior to unweeded maize for grain yield and its components (Table 8).
If average yields for the unweeded lots are set equal to $100 \%$, the average yields of the hoed lots (or of those with ground cover), in numbers of total green ears, marketable unhusked green ears and marketable husked green ears are (as percentages) equal to 107, 169 and 199, respectively (Table 4). In terms of weight, the respective yields will be 197, 270 and 333 (Table 6). For grain yield, the value is $241 \%$ (Table 8 ). Therefore, by eliminating weeds through physical, chemical and biological processes, ground cover promoted relatively small increases in the total number of green ears compared to unweeded maize. However, increases in other characteristics used to evaluate green-ear and grain yields resulted in almost double or more than double the yields obtained without weed control. 
Table 7 - Summary of the variance analysis for the characteristics of maize cultivars as a response to the methods of weed control (MWC)

\begin{tabular}{|c|c|c|c|c|}
\hline \multirow{2}{*}{ Source of variation } & \multirow{2}{*}{ Degrees of freedom } & Kernels (No ear-1) & 100-kernel weight (g) & Grain yield $\left(\mathrm{kg} \mathrm{ha}^{-1}\right)$ \\
\hline & & \multicolumn{3}{|c|}{ 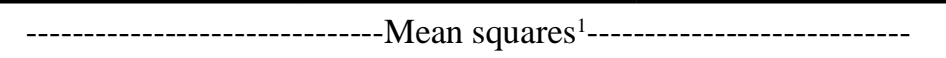 } \\
\hline Blocks & 9 & $3,975.4$ & 13.6 & $1,692,049.5$ \\
\hline Cultivars & 1 & $38,449.2 *$ & $46.1^{\mathrm{ns}}$ & $4,110,700.8^{\mathrm{ns}}$ \\
\hline Error 1 & 9 & $4,003.9$ & 27.4 & $2,924,141.9$ \\
\hline MWC & 5 & $92,773.8^{*}$ & $146.0 *$ & $50,363,068.0 * *$ \\
\hline C x MWC & 5 & $1,255.5^{\mathrm{ns}}$ & $6.3^{\mathrm{ns}}$ & $728,070.1^{\mathrm{ns}}$ \\
\hline Error 2 & 90 & $1,895.6$ & 7.0 & $1,415,771.1$ \\
\hline
\end{tabular}

${ }^{1} \mathrm{~ns}, *, * *$ Corresponding to a non-significant or significant effect at $5 \%$ or at $1 \%$ probability, respectively, by F-test

Table 8 - Mean values for the number of kernels per ear, 100-kernel weight and grain yield of maize cultivars as a response to the methods of weed control ${ }^{1}$

\begin{tabular}{|c|c|c|c|}
\hline Method of weed control ${ }^{2}$ & Kernels $\left(\right.$ No ear $\left.{ }^{-1}\right)$ & 100-kernel weight $(\mathrm{g})$ & Grain yield $\left(\mathrm{kg} \mathrm{ha}^{-1}\right)$ \\
\hline No hoeing & $285 \mathrm{~b}$ & $25.4 \mathrm{~b}$ & $2,731 \mathrm{~b}$ \\
\hline Two hoeings & $428 \mathrm{a}$ & $30.6 \mathrm{a}$ & $6,351 \mathrm{a}$ \\
\hline Ground cover of gliricidia branches & $468 \mathrm{a}$ & $31.8 \mathrm{a}$ & 6,534 a \\
\hline Ground cover of leucaena branches & $455 \mathrm{a}$ & $32.7 \mathrm{a}$ & $6,692 \mathrm{a}$ \\
\hline Ground cover of neem branches & $451 \mathrm{a}$ & $31.8 \mathrm{a}$ & 6,956 a \\
\hline Ground cover of sabiá branches & $443 \mathrm{a}$ & $32.1 \mathrm{a}$ & $6,352 \mathrm{a}$ \\
\hline \multicolumn{4}{|l|}{ Cultivar } \\
\hline AG 1051 & $440 \mathrm{~A}$ & $30.1 \mathrm{~A}$ & $6,264 \mathrm{~A}$ \\
\hline Al Bandeirantes & $404 \mathrm{~B}$ & $31.4 \mathrm{~A}$ & $5,826 \mathrm{~A}$ \\
\hline $\mathrm{CV}_{\text {plots }}(\%)$ & 15.0 & 17.0 & 28.8 \\
\hline $\mathrm{CV}_{\text {sublots }}(\%)$ & 10.0 & 8.6 & 20.0 \\
\hline
\end{tabular}

${ }^{1}$ Means followed by the same letter do not differ significantly at $5 \%$ probability by Tukey's test; ${ }^{2}$ Ground cover consisted of $30 \mathrm{t}$ ha ${ }^{-1}$ (fresh weight) of Gliricidia sepium, Leucaena leucocephala or Azadirachta indica

Positive effects of ground cover from neem, gliricidia and leucaena in reducing the growth of weeds and increasing crop yields have been seen by other authors (AHAIWE; NWAIGBO; ANO, 2010; IBE; ALAMU; OLANIYI, 2012). Prates, Pires and Pereira Filho (2003) found a reduction in the growth of weeds with ground cover from leucaena branches. Apparently, the first account of ground cover from sabiá branches reducing the growth of weeds and increasing maize yield appears in the present article. Sabia is a species that is native to the Caatinga and is at risk of extinction due to the extraction of its timber, which is greatly appreciated in the backlands of the Northeast (MAIA, 2004).

\section{CONCLUSIONS}

1. Carrying out two hoeings was more effective at reducing weed growth than ground cover consisting of $30 \mathrm{t} \mathrm{ha}^{-1}$ of branches of the neem, gliricidia, leucaena and sabiá;

2. Hoeing and ground cover gave similar yields of green ears and grain, which were higher than those seen in unweeded maize;

3. The cultivars did not differ as to green ear or grain yield. 


\section{REFERENCES}

AHAIWE, M. O.; NWAIGBO, L. C.; ANO, A. O. Influence of plant prunings on soil properties and yield of yam minisett. Journal of Agriculture and Social Research, v. 10, n. 2, p. 172177, 2010.

BERTALOT, M. J. A. et al. Desempenho da cultura do milho (Zea mays L.) em sucessão com aveia-preta (Avena strigosa Schreb.) sob manejos agroflorestal e tradicional. Revista Árvore, v. 34, n. 4, p. 597-608, 2010.

CARDINA, J.; JOHNSON, G. A.; SPARROW, D. H. The nature and consequence of weed spatial distribution. Weed Science, v. 45, n. 3, p. 364-373, 1997.

CARMO FILHO, F.; OLIVEIRA, O. F. Mossoró: um município do semi-árido nordestino. Mossoró: Fundação Guimarães Duque: ESAM, 1989. 62 p. (Coleção Mossoroense. Série B, 672).

CARVALHO, J. E. U. Utilização de espécies frutíferas em sistemas agroflorestais na Amazônia: capital social na concepção de políticas públicas: a importância socioeconômica e ecológica dos sistemas agroflorestais frente aos mecanismos de desenvolvimento. In: GAMARODRIGUES, A. C. et al. (Org.). Sistemas agroflorestais: bases científicas para o desenvolvimento sustentável. Campos dos Goytacazes: Editora da Universidade Estadual do Norte Fluminense Darcy Ribeiro, 2006. p. 169-176.

CHOU, C. H.; KUO, Y. L. Allelopathic research of subtropical vegetation in Taiwan. III. Alelopathic exclusion of understory by Leucaena leucocephala (Lam.) de Wit. Journal of Chemical Ecology, v. 12, n. 6, p. 1431-1448, 1986.

DRUMOND, M. A.; MORGADO, L. B. Espécies arbóreas alternativas para sistemas agroflorestais no semi-árido brasileiro. Agrossilvicultura, v. 1, n. 1, p. 43-50, 2004.

EMPRESA BRASILEIRA DE PESQUISA AGROPECUÁRIA. Centro Nacional de Pesquisa do Solo. Sistema Brasileiro de Classificação de Solos. Brasília: Serviço de Produção de Informação, 2006. 306 p.

FERREIRA, E. G. B. S. et al. Efeito alelopático do extrato aquoso de sabiá na germinação de sementes de fava. Revista Ciência Agronômica, v. 41, n. 3, p. 463-467, 2010.

IBE, R. B.; ALAMU, O. O.; OLANIYI, O. W. Economic analysis of the effect from mulch on weed control and yield of okra (Abelmoschus esculentus L. Moench). Nigerian Journal of Horticultural Science, v. 17, n. 1, p. 80-87, 2012.

KIILL, L. H. P.; MENEZES, E. A. Espécies vegetais exóticas com potencialidades para o semi-árido brasileiro. Brasília: Embrapa Informação Tecnológica, 2005. 340 p.

LOJKA, B. et al. Diversity of shifting cultivation cycles among small-scale farmers in Peruvian Amazon. Agricultural Sciences, v. 2, n. 2, p. 68-77, 2011.

MAIA, G. N. Caatinga: árvores e arbustos e suas utilidades. São Paulo: D\&Z Computação Gráfica e Editora, 2004. 413 p.
MAMEDE, M. A.; ARAÚJO, F. S. Effects of slash and burn practices on a soil seed bank of caatinga vegetation in Northeastern Brazil. Journal of Arid Environments, v. 72, n. 3, p. 458-470, 2008.

MASHINGAIDZE, N. et al. Crop yield and weed growth under conservation agriculture in semi-arid. Soil \& Tillage Research, v. 124 , n. 1, p. 102-110, 2012.

MULVANEY, M. J.; PRICE, A. J.; WOOD, C. W. Cover crop residue and organic mulches provide weed control during limited-input no-till collard production. Journal of Sustainable Agriculture, v. 35, n. 3, p. 312-328, 2011.

OMOVBUDE, S.; UDENSI, E. U. Profitability of selected weed control methods in maize (Zea mays L.) in Nigeria. Journal of Animal \& Plant Sciences, v. 15, n. 1, p. 2109-2117.

PANDEY, C. B.; SHARMA, D. K.; BARGALI, S. S. Decomposition and nitrogen release from Leucaena leucocephala in central India. Tropical Ecology, v. 47, n. 1, p. 149-151, 2006.

PEREZ-MARIN, A. M.; MENEZES, R. S. C.; SALCEDO, I. H. Produtividade de milho solteiro ou em aléias de gliricídia adubado com duas fontes orgânicas. Pesquisa Agropecuária Brasileira, v. 42, n. 5, p. 669-677, 2007.

PITELlI, R.; DURIGAN, J. C. Ecologia das plantas daninhas no sistema de plantio direto. In: ROSSELLO, R. D. Siembra directa en el Cono Sur. Montevideo: PROCISUR, 2001. p. 203-210.

PRATES, H. T.; PIRES, N. M.; PEREIRA FILHO, I. A. Controle de plantas daninhas na cultura do milho utilizando leucena (Leucena leucocephala (Lam.) De Wit). Revista Brasileira de Milho e Sorgo, v. 2, n. 2, p. 36-43, 2003.

QUEIROZ, L. R. et al. Supressão de plantas daninhas e produção de milho-verde orgânico em sistema de plantio direto. Planta Daninha, v. 28, n. 2, p. 263-270, 2010.

QUEIROZ, L. R. et al. Cultivo de milho no sistema de aléias com leguminosas perenes. Ciência e Agrotecnologia, v. 31, n. 5, p. 1303-1309, 2007.

RAHMAN, S. A. et al. Analysis of the economic benefits from systematic improvements to shifting cultivation and its evolution towards stable continuous agroforestry in the upland of Eastern Bangladesh. International Forestry Review, v. 9, n. 1, p. 536-547, 2007.

RAJASHEKARAPPA, K. S.; BASAVARAJAPPA, B. E.; PUTTAIAH, E. T. Effect from different organic mulches and in situ green manuring on soil properties and yield and economics of maize in south-eastern dry zone of Karnataka. Global Journal of Biology Agriculture \& Health Sciences, v. 2, n. 3, p. 236-240, 2013.

RAMAMOORTHY, M; PALIWAL. K. Allelopathic compounds of Gliricidia sepium (Jacq.) Kunth ex Walp. and its effect on Sorghum vulgare L. Journal of Chemical Ecology, v. 19, n. 8, p. 1691-1701, 1993. 
SCHROTH, G.; RUF, F. Farmer strategies for tree crop diversification in the humid tropics. A review. Agronomy for Sustainable Development, v. 34, n. 1, p. 139-154, 2014.

SILVA, J. P. et al. Antifeedant and allelopatic activities of the hydroalcoholic extract obtained from neem (Azadirachta indica) leaves. Revista Brasileira de Farmacognósia, v. 17, n. 4, p. 529-532, 2007.
TIESSEN, H.; SALCEDO, I. H.; SAMPAIO, E. V.S. B. Nutrient and soil organic matter dynamics under shifting cultivation in semi-arid northeastern Brazil. Agriculture, Ecosystem and Environment, v. 38, n. 1, p. 139-151, 1992.

ZYSTRO, J. P.; LEON, N.; TRACY, W. F. Analysis of traits related to weed competitiveness in sweet corn (Zea mays L.). Sustainability, v. 4, n. 4, p. 543-560, 2012. 